\title{
Levomethadyl Acetate Hydrochloride
}

National Cancer Institute

\section{Source}

National Cancer Institute. Levomethadyl Acetate Hydrochloride. NCI Thesaurus. Code C47583.

The hydrochloride salt form of levomethadyl acetate, a synthetic mu-receptor agonist with analgesic activity. Levomethadyl acetate hydrochloride mimics the actions of endogenous peptides at CNS opioid receptors, including analgesia, euphoria, sedation, respiratory depression, miosis, bradycardia and physical dependence. Levomethadyl acetate hydrochloride has less severe withdrawal symptoms compared to the morphinelike agents. In addition, with chronic use, levomethadyl acetate hydrochloride produces cross-tolerance to the effects of other mu-receptor agonists, thereby decreasing the physical dependence. 